\title{
Mercury in the North Atlantic Ocean: The U.S. GEOTRACES zonal and meridional sections
}

\author{
Katlin L. Bowman ${ }^{\mathrm{a}}$, Chad R. Hammerschmidt ${ }^{\mathrm{a}}$, Carl H. Lamborg ${ }^{\mathrm{b}}$, Gretchen Swarr ${ }^{\mathrm{b}}$ \\ ${ }^{\mathrm{a}}$ Corresponding author (K. Bowman) \\ 260 Brehm Laboratory \\ Department of Earth \& Environmental Science \\ Wright State University \\ 3640 Colonel Glenn Hwy, Dayton, OH, 45435, USA \\ Email: bowman.49@wright.edu (330-261-1039),chad.hammerschmidt@wright.edu \\ b266 Woods Hole Rd. MS\#51 \\ Marine Chemistry \& Geochemistry \\ Woods Hole Oceanographic Institution, Woods Hole, MA, 02543-1050, USA \\ Email:clamborg@whoi.edu,gswarr@whoi.edu
}

\begin{abstract}
Mercury $(\mathrm{Hg})$ in the ocean undergoes many chemical transformations, including in situ production of monomethylmercury $(\mathrm{MMHg})$, the form that biomagnifies in marine food webs. Because the ocean is a primary and dynamic reservoir of $\mathrm{Hg}$ cycling at earth's surface and the principal source of human MMHg exposures through seafood, it is important to understand the distribution of $\mathrm{Hg}$ and its chemical species in marine environments. We examined total $\mathrm{Hg}$, elemental $\mathrm{Hg}\left(\mathrm{Hg}^{0}\right), \mathrm{MMHg}$, and dimethylmercury (DMHg) with fully resolved high-resolution profiles during the U.S. GEOTRACES zonal and meridional sections of the North Atlantic Ocean (GEOTRACES GA03). Total Hg in filtered water had both scavenged- and nutrient-type vertical distributions, whereas concentrations of $\mathrm{DMHg}, \mathrm{Hg}^{0}$, and filtered $\mathrm{MMHg}$ were increased in the oxygen deficient zone of the permanent thermocline across the basin, relative to water above and often below. Total Hg and MMHg on suspended particles accounted for less than $10 \%$ of total concentrations. The TAG hydrothermal vent on the Mid-Atlantic Ridge (MAR) was a
\end{abstract}


source of total $\mathrm{Hg}$ and $\mathrm{MMHg}$ to nearby waters with apparent scavenging and $\mathrm{Hg}$ transformation occurring in the buoyant plume. Uniquely, we observed significant horizontal segregation of filtered total $\mathrm{Hg}$ and $\mathrm{MMHg}, \mathrm{DMHg}$, and $\mathrm{Hg}^{0}$ in North Atlantic Deep Water (NADW) between younger water on the western and older water on the eastern side of the MAR. Relative to eastern NADW, Hg concentrations in western NADW were greater, on average, by $1.14 \times$ for filtered total $\mathrm{Hg}, 1.6 \times$ for $\mathrm{Hg}^{0}, 2.5 \times$ for filtered MMHg, and 2.6 $\times$ for DMHg. Total Hg enrichment in deep water of the western basin may have resulted from downwelling of anthropogenic $\mathrm{Hg}$ during NADW formation. Enrichment of MMHg, DMHg, and $\mathrm{Hg}^{0}$ in western basin NADW may be explained by either greater $\mathrm{Hg}$ substrate availability or greater methylation and reduction potentials in younger deep waters.

Keywords: methylmercury, hydrothermal, deep water, scavenging 


\section{Introduction}

Mercury $(\mathrm{Hg})$ is a ubiquitous environmental contaminant that originates from natural and anthropogenic sources (Fitzgerald et al., 2007). Direct atmospheric deposition is the primary source of $\mathrm{Hg}$ to the ocean whereas riverine discharge, mobilization from sediments, groundwater, and submarine hydrothermal inputs contribute lesser amounts (Mason et al., 2012). The majority of atmospheric Hg emissions are anthropogenic (Fitzgerald et al., 1998; Amos et al., 2013) and emissions are hypothesized to increase during the next century (Hammerschmidt, 2011; Kocman et al., 2013; Pirrone et al., 2010; Streets et al., 2009). Because the ocean is a primary and dynamic reservoir of $\mathrm{Hg}$ cycling at earth's surface and the principal source of human $\mathrm{Hg}$ exposures through seafood (Mason et al., 2012), it is important to understand the distribution of $\mathrm{Hg}$ and its chemical species in marine environments.

Mercury exists as four primary chemical species in seawater: mercuric ion $(\mathrm{Hg}(\mathrm{II}))$ and monomethylmercury $\left(\mathrm{MMHg}, \mathrm{CH}_{3} \mathrm{Hg}^{+}\right)$in complexes with inorganic and organic ligands as well as elemental $\mathrm{Hg}\left(\mathrm{Hg}^{0}\right)$ and dimethylmercury $\left(\mathrm{DMHg},\left(\mathrm{CH}_{3}\right)_{2} \mathrm{Hg}\right)$, which are dissolved gases. Each of these species are hypothesized to be linked through the $\mathrm{Hg}(\mathrm{II})$ pool (Fitzgerald et al., 2007). For example, $\mathrm{Hg}(\mathrm{II})$ may be either reduced to $\mathrm{Hg}^{0}$ or transformed to $\mathrm{MMHg}$ and $\mathrm{DMHg}$ by biological and abiotic mechanisms (Monperrus et al., 2007; Whalin et al., 2007; Lehnherr et al., 2011). $\mathrm{Hg}(\mathrm{II})$ reduction occurs to such an extent that $\mathrm{Hg}^{0}$ in estuarine and marine surface waters are usually supersaturated with respect to the atmosphere, leading to evasion (Andersson et al., 2011). Moreover, in situ methylation of $\mathrm{Hg}(\mathrm{II})$ is an important source of $\mathrm{MMHg}$ and $\mathrm{DMHg}$ in many marine ecosystems (Balcom et al., 2004; Hammerschmidt and Fitzgerald, 2006a; Sunderland et al., 2009; Hollweg et al., 2010; Cossa et al., 2011). MMHg is the bioaccumulative species of $\mathrm{Hg}$ that is present throughout the marine water column (Hammerschmidt and Bowman, 2012; Heimbürger et al., 2010; Mason et al., 2012). Harmful to humans and piscivorous wildlife, MMHg can 
interfere with neurological, cardiovascular, and endocrine systems (Bose-O'Reilly et al., 2010; Scheuhammer et al., 2007; Zahir et al., 2005). In the United States and Europe, consumption of marine fish is the primary route of human exposure to MMHg (Sunderland, 2007; Višnjevec et al., 2014).

We investigated the speciation and distribution of $\mathrm{Hg}$ in the North Atlantic Ocean during the U.S. GEOTRACES zonal and meridional sections in Fall 2010 and Fall 2011 (GEOTRACES GA03; Figure 1). These cruise tracks included multiple oceanographic features that may influence the biogeochemical cycling of $\mathrm{Hg}$ species: 1) a broad continental shelf on the western margin, 2) oligotrophic surface waters in the Sargasso Sea, 3) the Mid-Atlantic Ridge with active hydrothermal venting, 4) relatively productive surface waters along the eastern margin as a result of upwelling and Saharan dust inputs, 5) multiple deep and intermediate water masses (Figure 2), and 6) age differences of North Atlantic Deep Water (NADW) between the western and eastern sides of the Mid-Atlantic Ridge. We measured high-resolution vertical profiles of $\mathrm{Hg}^{0}$, $\mathrm{DMHg}$, $\mathrm{MMHg}$, and total $\mathrm{Hg}$ in filtered water at 32 stations across the North Atlantic as well as particulate total $\mathrm{Hg}$ and $\mathrm{MMHg}$ at 22 stations to assemble the most comprehensive and resolved distribution of $\mathrm{Hg}$ species in any ocean basin. Here, we provide the first descriptive presentation of our speciation results.

\section{Materials and Methods}

\subsection{Sample collection}

Seawater was sampled with 12-L Teflon-coated Go-Flo bottles attached to a dedicated trace-metal clean rosette that was deployed with a plastic-coated hydrowire (Cutter and Bruland, 2012). Twenty full-depth stations (24 36 depths) and 12 "demi" stations (12 depths each in 
upper $1000 \mathrm{~m}$ ) were sampled and analyzed for $\mathrm{Hg}$ species in filtered water. Go-Flo bottles were promptly transferred to a clean laboratory van where seawater was filtered without agitation through pre-rinsed capsules ( $0.2 \mu \mathrm{m}$ Pall AcroPak-200) into 2-L Teflon bottles for determination of DMHg, $\mathrm{Hg}^{0}$, and MMHg. An additional 0.2-L aliquot of filtered seawater was collected into 0.25-L borosilicate glass bottles for measurement of total Hg. Each sample bottle, which was cleaned rigorously with vetted methods (Hammerschmidt et al., 2011), was rinsed $3 \times$ with sample water (about $10 \%$ bottle volume) before filling.

Suspended particles $(1-51 \mu \mathrm{m})$ were sampled from 16 depths at 22 stations onto quartz fiber filters (Whatman QMA) with McLane in situ pumps (Bishop et al., 2012). Filters were subsampled in a clean laboratory into $25-\mathrm{mm}$ diameter punches and stored frozen until $\mathrm{Hg}$ analysis at Wright State University. The volume of seawater passed through each 25-mm filter subsample ranged from about 25 to $100 \mathrm{~L}$.

\subsection{Mercury analysis}

Hg species in filtered seawater were extracted and quantified on board the research vessel inside a clean laboratory van, which was separate from other GEOTRACES laboratories to prevent potential sample contamination from $\mathrm{Hg}^{0}$ released to the air from mercury electrodes used by other researchers. Within $2 \mathrm{~h}$ of water sampling and filtration, gaseous $\mathrm{Hg}^{0}$ and $\mathrm{DMHg}$ were extracted from 2-L samples by purging with $\mathrm{Hg}$-free $\mathrm{N}_{2}\left(30 \mathrm{~L}\right.$ total at $0.8 \mathrm{~L} \mathrm{~min}^{-1}$; Bowman and Hammerschmidt, 2011). The sample bottles were fitted with multi-port caps (Omnifit Qseries; Danbury, CT) that allowed influent $\mathrm{N}_{2}$ to flow through fritted glass impingers while effluent gas exited through a series of three collection traps connected by Teflon fittings. The first trap contained reagent-grade soda lime to help remove water vapor/aerosols generated from 
purging, the second contained Tenax TA to concentrate DMHg, and the third contained Aucoated glass beads to collect $\mathrm{Hg}^{0}$ (Lamborg et al., 2012). This extraction and trapping approach allows for DMHg and $\mathrm{Hg}^{0}$ to be determined independently as opposed to trapping both species on $\mathrm{Au}$ as generic dissolved gaseous mercury (DGM). It also allows for species-specific differentiation of DMHg and $\mathrm{MMHg}$, which are more commonly determined as total methylated mercury $\left(\mathrm{CCH}_{3} \mathrm{Hg}\right)$ after sample acidification (Mason et al., 2012). DMHg was quantified after thermal desorption from Tenax by gas chromatographic cold vapor atomic fluorescence spectrometry (GC-CVAFS, Bloom, 1989; Bowman and Hammerschmidt, 2011) and $\mathrm{Hg}^{0}$ by dual Au-amalgamation CVAFS (Bloom and Fitzgerald, 1988). Each Au-trap for analysis of $\mathrm{Hg}^{0}$ was calibrated at every other station after direct loading with a known quantity of $\mathrm{Hg}^{0}$ vapor. Procedural precision of $\mathrm{Hg}^{0}$ determinations averaged $10 \pm 6$ relative percent difference (RPD; $n$ $=5$ pairs) between duplicate samples. Tenax traps for DMHg analysis were calibrated frequently between stations with known additions of methylethylmercury, a volatile derivative of MMHg. Procedural precision of DMHg analyses averaged 16 \pm 18 RPD between 16 pairs of samples. The number of duplicate samples for $\mathrm{DMHg}, \mathrm{Hg}^{0}$, and $\mathrm{MMHg}$ analysis was low relative to the total number of samples because water budgets for the Go-Flo bottles were extremely limited, particularly for an extra $2 \mathrm{~L}$ of water. Method detection limits were $0.01 \mathrm{pM}$ for $\mathrm{Hg}^{0}$ and 0.002 pM for DMHg.

After quantitatively stripping $\mathrm{Hg}^{0}$ and DMHg from solution, water samples were transferred to 2-L polycarbonate bottles and acidified to $1 \%$ with trace-metal grade $\mathrm{H}_{2} \mathrm{SO}_{4}$ for MMHg determination (Bowman and Hammerschmidt, 2011). After $1224 \mathrm{~h}$, sample acidity was neutralized with $12 \mathrm{M} \mathrm{KOH}, \mathrm{pH}$ adjusted to 5 with $4 \mathrm{M}$ acetate buffer, and ethylated with sodium tetraethylborate (NaTEB). Low-Hg acetate buffer was prepared from acetic acid and 
$\mathrm{KOH}$, as opposed to acetic acid and sodium acetate because the sodium salt can contain significant amounts of total $\mathrm{Hg}$ and MMHg. Sample bottles were fitted with multi-port caps and purged with air ( $30 \mathrm{~L}$ total at $0.8 \mathrm{~L} \mathrm{~min}^{-1}$ ) that was cleaned of $\mathrm{Hg}$ by passing over $\mathrm{Au}$ and Carbotrap. Effluent gas from the bottles passed through soda lime before methylethylmercury was concentrated on Tenax. MMHg was quantified by GC-CVAFS (Bloom, 1989; Bowman and Hammerschmidt, 2011). Recovery of known additions of MMHg from seawater averaged $105 \pm$ $6 \%(n=3)$ and procedural precision averaged $13 \pm 13$ RPD between 14 pairs of duplicate samples. Individual Tenax traps were calibrated frequently between stations with aliquots of an aqueous $\mathrm{MMHgCl}$ standard; the standard was calibrated versus digested TORT-2 reference material (lobster hepatopancreas, National Research Council of Canada) every two weeks.

Total $\mathrm{Hg}$ in filtered seawater was measured within $48 \mathrm{~h}$ of sampling from $0.2-\mathrm{L}$ aliquots separate from those used for $\mathrm{Hg}^{0}$ and organo- $\mathrm{Hg}$ species. Water was oxidized with $\mathrm{BrCl}$ solution ( $0.1 \%$ by volume) for $>12 \mathrm{~h}$ and pre-reduced with $\mathrm{NH}_{2} \mathrm{OH}$ immediately prior to analysis. Oxidized $\mathrm{Hg}$ species were reduced to $\mathrm{Hg}^{0}$ with $\mathrm{SnCl}_{2}$, purged from solution with custom-made UConn Bubblers (Lamborg et al., 2012), and quantified by dual Au-amalgamation CVAFS (Bloom and Fitzgerald, 1988; Fitzgerald and Gill, 1979), after calibration with aqueous $\mathrm{Hg}(\mathrm{II})$ standards that were traceable to the U.S. National Institute of Standards and Technology (NIST). The method detection limit for total $\mathrm{Hg}$ in filtered seawater was $0.02 \mathrm{pM}$. Recovery of known additions of aqueous $\mathrm{Hg}(\mathrm{II})$ averaged $99 \pm 5 \%(n=12)$ and near-weekly measurements of total Hg in BCR-579 (Total Mercury in Coastal Seawater, European Commission) averaged 10.3 \pm $0.6 \mathrm{pmol} / \mathrm{kg}(n=5)$, which was within the certified range of $9.5 \pm 2.5 \mathrm{pmol} / \mathrm{kg}$. Procedural precision of total $\mathrm{Hg}$ measurements in filtered seawater averaged $5 \pm 5$ RPD between 18 pairs of samples. 
Filter punches containing suspended particulate matter were stored frozen $\left(\leq-20^{\circ} \mathrm{C}\right)$ until analysis at Wright State University within two to three months of sampling. Mercury was leached from filters with high-purity $2 \mathrm{~N} \mathrm{HNO}_{3}$ for $4 \mathrm{~h}$ in a $60{ }^{\circ} \mathrm{C}$ water bath (Hammerschmidt and Fitzgerald, 2006b). Aliquots of digestate were analyzed for MMHg by flow-injection GCCVAFS (Tseng et al., 2004) after calibration with procedural MMHg standards digested similarly in $2 \mathrm{~N} \mathrm{HNO}_{3}$. MMHg standards for analysis of particulate $\mathrm{MMHg}$ were calibrated against aqueous $\mathrm{Hg}(\mathrm{II})$ solutions traceable to the U.S. NIST. Particulate total $\mathrm{Hg}$ was determined from the same digestates used for MMHg analysis. Aliquots of digestates were oxidized with $\mathrm{BrCl}$, pre-reduced with $\mathrm{NH}_{2} \mathrm{OH}$, reduced with $\mathrm{SnCl}_{2}$, and analyzed by dual Au-amalgamation CVAFS (Hammerschmidt and Fitzgerald, 2006b). The method detection limit for particulate MMHg was $0.002 \mathrm{pM}$ and that for total $\mathrm{Hg}$ was $0.03 \mathrm{pM}$. Due to low analyte concentrations and limited sample volumes, analytical precision of particulate $\mathrm{Hg}$ determinations was assessed only during analysis of total $\mathrm{Hg}$ : precision of analytical replicates averaged $3 \pm 3 \operatorname{RPD}(n=18)$.

Trace-metal clean procedures were followed throughout sample collection and processing. Collection and filtration methods, sample bottle materials and cleaning techniques, and analytical methods were evaluated rigorously during the U.S. GEOTRACES Intercalibration cruises in the Atlantic and Pacific Oceans, prior to the North Atlantic sections (Bowman and Hammerschmidt, 2011; Hammerschmidt et al., 2011; Bishop et al., 2012; Lamborg et al., 2012; Cutter and Bruland, 2012). 


\section{Results and Discussion}

\subsection{Physical oceanography of the basin}

The zonal and meridional sections traversed multiple water masses in the North Atlantic Ocean (Figure 2). The largest water mass in the North Atlantic is NADW, which occupies the water column from about 1500 to $4000 \mathrm{~m}$ depth. The dominant flow of newly formed NADW is from the Labrador and Norwegian Seas into the western basin of the North Atlantic. Not until the Romanche Fracture Zone, south of the equator, does some NADW return northward and ventilate the abyss on the eastern side of the Mid-Atlantic Ridge. This path of deep water flow results in NADW of the western basin ( $~ 90 \mathrm{y}$ old near Bermuda) having a radiocarbon age about 150 y younger than the eastern basin ( $\sim 240$ y old; Broecker et al., 1991). These age differences of NADW between the eastern and western basin are related to the speciation and concentration of $\mathrm{Hg}$ in NADW, as discussed below and elsewhere (Lamborg et al., accepted).

\subsection{Total $\mathrm{Hg}$}

Among all stations and depths in the North Atlantic, total $\mathrm{Hg}$ in filtered water ranged from 0.09 to $1.9 \mathrm{pM}$ (Table 1), excluding waters sampled from the TAG hydrothermal plume on the Mid-Atlantic Ridge (Station 16), which is discussed in section 3.6. The mean concentration of filtered total $\mathrm{Hg}$ in our study $(0.89 \pm 0.30 \mathrm{pM})$ is less than half of that determined from other locations in the North (Mason et al., 1998) and equatorial and South Atlantic (Mason and Sullivan, 1999) about two decades earlier. Lower concentrations in the current study may be attributed to decreased atmospheric inputs of $\mathrm{Hg}$ to the North Atlantic during the past 20 years (Ebinghaus et al., 2011). Alternatively, the difference may reflect on-going improvements in clean techniques for sampling and analysis of $\mathrm{Hg}$ in seawater, particularly as a result of testing 
and development during the U.S. GEOTRACES Intercalibration (Hammerschmidt et al., 2011; Lamborg et al., 2012).

Total Hg in filtered water had both scavenged- and nutrient-type vertical distributions in the North Atlantic (Figure 3a). The concentration of filtered total Hg in the upper $100 \mathrm{~m}$ of the water column averaged $0.65 \pm 0.32 \mathrm{pM}(n=103)$ among all stations during both meridional and zonal sections and were much less than concentrations in deeper water. Relative to surface water, concentrations of filtered total $\mathrm{Hg}$ were increased in the oxygen deficient zone (ODZ), extending from east to west across the North Atlantic (Figure 3a), consistent with release of Hg from sinking particles during remineralization. Strong scavenging of total $\mathrm{Hg}$ from surface waters was evident in the eastern Atlantic, where dust deposition and upwelling promote biological productivity and either bioaccumulation or scavenging of $\mathrm{Hg}$ from solution.

Horizontal segregation of filtered total $\mathrm{Hg}$ was evident in NADW, excluding the hydrothermal plume on the Mid-Atlantic Ridge that had concentrations of filtered total $\mathrm{Hg}$ up to $13 \mathrm{pM}$. We have hypothesized that $\mathrm{Hg}$ slowly accumulates in deep waters of the ocean as a result of soft-tissue remineralization at depth, resulting in older deep waters (e.g., North Pacific) having greater concentrations than younger deep water (e.g., North Atlantic; Hammerschmidt and Bowman, 2012; Lamborg et al., accepted). In contrast, younger NADW in the western North Atlantic (Stations 1-15, zonal transect) has a mean concentration of filtered total $\mathrm{Hg}(1.04 \pm 0.17$ $\mathrm{pM}, n=65$ ) that is about $15 \%$ greater than that in approximately 150 -y older NADW in the eastern basin $($ mean $=0.91 \pm 0.23 \mathrm{pM}, n=68$; Mann-Whitney rank sum, $p<0.001)$, disregarding the TAG hydrothermal station on the Mid-Atlantic Ridge (Station 16). Greater concentrations of filtered total $\mathrm{Hg}$ in younger NADW of the western basin compared to the eastern North Atlantic have been attributed to younger NADW having downwelled anthropogenic $\mathrm{Hg}$ during deep 
water formation (Lamborg et al., accepted). Such a source would be in addition to the natural and anthropogenic Hg that is added to deep waters on both sides of the Mid-Atlantic Ridge as a result of particle scavenging and remineralization. In water deeper than $4000 \mathrm{~m}$, which is a combination of NADW and Antarctic Bottom Water (AABW; Jenkins et al., in review), concentrations of filtered total $\mathrm{Hg}(1.3 \pm 0.1 \mathrm{pM})$ were greater than those in NADW and comparable to concentrations in AABW in the Southern Ocean $(1.4 \pm 0.4 \mathrm{pM}$; Cossa et al., 2011). The similarity of concentrations between the deepest waters of the North Atlantic and those in young AABW suggests that $\mathrm{Hg}$ is not effectively scavenged from deep waters on time scales of less than 300 years. Ineffective scavenging may result from either an attenuated particle flux at depth (Antia et al., 2001) or Hg existing predominantly as either complexes (e.g., Hgorganic ligands; Fitzgerald et al., 2007) or redox species $\left(\mathrm{Hg}^{0}\right.$, described below) that are less relative to particles. With the exception of zonal Stations 2, 3, and 6 on the northwest continental margin, filtered total $\mathrm{Hg}$ was not more concentrated in water overlying the sediment interface, suggesting that diffusion and advection of dissolved and colloidal Hg from deep-sea sediments is not an important source to the ocean.

Total $\mathrm{Hg}$ in suspended particles accounted for less than $10 \%$ of $\mathrm{Hg}$ in the water column of the North Atlantic, with much greater concentrations in surface waters than at depth (Figure 3b). The vertical distribution of particulate total $\mathrm{Hg}$ is consistent with that of particulate organic matter in the North Atlantic (Antia et al., 2001). The mean concentration of particulate total $\mathrm{Hg}$ along the U.S. GEOTRACES sections (Table 1; $0.038 \pm 0.039 \mathrm{pM}$ ) is similar to that determined by Mason and colleagues (1998) in surface waters of the North Atlantic between 50 and $70{ }^{\circ} \mathrm{N}$ $(0.035 \pm 0.02 \mathrm{pM})$. Similar concentrations of particulate total $\mathrm{Hg}$ between this study and that of Mason and co-workers (1998) further suggest that concentrations of filtered total Hg determined 
in the previous study may be artificially high, unless there has been a significant change in particle-water partitioning of $\mathrm{Hg}$ in the North Atlantic during the past 20 years. Elevated concentrations of total $\mathrm{Hg}$ on suspended particles (but not in filtered water) were observed in benthic nephloid layers at meridional Station 9 in the eastern Atlantic and zonal Stations 4, 8, and 10 in the western Atlantic (Figure 3b). Particles enriched with metal-oxides apparently scavenge $\mathrm{Hg}$ in the TAG hydrothermal plume, which is discussed in section 3.6.

\subsection{Elemental $\mathrm{Hg}$}

Elemental Hg has a complex vertical and horizontal distribution across the North Atlantic (Figure 4). Elemental Hg is the product of both photochemical and biological mechanisms that reduce $\mathrm{Hg}(\mathrm{II})$ substrates (Costa and Liss, 1999; Rolfhus and Fitzgerald, 2004; Poulain et al., 2007) as well as biological and photochemical demethylation of methylated Hg (Mason and Fitzgerald, 1993; Lehnherr et al., 2011), with both biological reduction and demethylation potentially mediated by the mer-operon, including at sub-picomolar $\mathrm{Hg}$ concentrations (Barkay et al., 2003). Concentrations of $\mathrm{Hg}^{0}$ varied nearly 100-fold within the North Atlantic (Table 1), with levels in thermocline and deep waters typically exceeding those in the upper $100 \mathrm{~m}$ of the water column (mean $=0.15 \pm 0.12 \mathrm{pM}, n=109$ ). Levels of $\mathrm{Hg}^{0}$ in the mixed layer of the North Atlantic at our sampling locations between 17 and $40^{\circ} \mathrm{N}$ are much less than those measured between 50 and $70{ }^{\circ} \mathrm{N}(0.65 \pm 0.39 \mathrm{pM}$; Mason et al., 1998). Elemental Hg at the sea surface, sampled underway at $2 \mathrm{~m}$ depth with a towed fish, averaged $0.05 \pm 0.03 \mathrm{pM}(n=24)$.

Vertical profiles of $\mathrm{Hg}^{0}$ had a distinct nutrient-type distribution that closely followed that of total filtered $\mathrm{Hg}$ and nitrate in the western North Atlantic (zonal Stations 1-12 and 14), as shown for Station 12 (Figure 5a). This distribution was unexpected because nutrient-type profiles 
of $\mathrm{Hg}^{0}$ had not been documented previously. Moreover, photochemical and microbial reduction of $\mathrm{Hg}(\mathrm{II})$ in surface waters can lead to supersaturation of $\mathrm{Hg}^{0}$ with respect to the atmosphere (Andersson et al., 2011), suggesting that maximum rather than minimum concentrations might be observed at the surface. In the western basin, $\mathrm{Hg}^{0}$ concentrations increased with depth from the surface, were greatest in the ODZ, and relatively homogenous at greater depths. In contrast, at stations in the eastern North Atlantic (zonal Stations 16-24, and meridional Stations 11-12), $\mathrm{Hg}^{0}$ was maximum in the ODZ with much lower concentrations in sub-thermocline waters (Figure 5b). Both $\mathrm{Hg}^{0}$ concentrations and the fraction of filtered total $\mathrm{Hg}$ as $\mathrm{Hg}^{0}$ in NADW differed significantly between the western and eastern North Atlantic (Mann-Whitney rank sum, $p$-values $<0.001)$. The mean concentration of $\mathrm{Hg}^{0}$ in western NADW $(0.42 \pm 0.09 \mathrm{pM}, n=66)$ was nearly twice that of eastern NADW $(0.26 \pm 0.10 \mathrm{pM}, n=72)$. Likewise, the fraction of filtered total $\mathrm{Hg}$ as $\mathrm{Hg}^{0}$ in NADW also was greater in the western $(42 \pm 8 \%, n=63)$ than eastern $\operatorname{basin}(30 \pm 15 \% n=59)$.

One potential explanation for the horizontal segregation of $\mathrm{Hg}^{0}$ in NADW is that $\mathrm{Hg}^{0}$ is downwelled during NADW formation in the Labrador and Norwegian Seas and slowly oxidized as the water ages. A study of $\mathrm{Hg}$ in the sub-polar North Atlantic near locations of NADW formation found that $\mathrm{Hg}^{0}$ was produced in the mixed layer and conserved as the water mass was formed and sank to depth (Mason et al., 1998). Concentrations of $\mathrm{Hg}^{0}$ in NADW in the western North Atlantic $(0.42 \pm 0.09 \mathrm{pM})$ are not different from those in surface waters of the Norwegian Sea $(0.35 \pm 0.18 \mathrm{pM}$; Mason et al., 1998) and support this hypothesis. However, a more recent study found concentrations of DGM ( $>90 \%$ as $\mathrm{Hg}^{0}$ in surface water; Mason et al., 1998) were $0.1 \mathrm{pM}$ or less in surface waters of the Labrador Sea (Andersson et al., 2008), which is a source region for NADW formation and contradicts this hypothesis. Measurements of $\mathrm{Hg}^{0}$ in NADW 
along a meridional section of the western North Atlantic, ideally between the equator and Labrador and Norwegian Seas, would help validate whether $\mathrm{Hg}^{0}$ is conserved during the first century of deep water flow.

Alternatively, $\mathrm{Hg}^{0}$ concentrations in deep water may represent a balance between in situ reduction and oxidation reactions. While photochemical processes are thought to be the primary mechanism of $\mathrm{Hg}$ reduction in the surface ocean (Rolfhus and Fitzgerald, 2004), the concentration maximum of $\mathrm{Hg}^{0}$ that extends across the Atlantic in the $\mathrm{ODZ}$ is indicative of a dark reaction leading to its formation at depth, likely coincident with organic matter remineralization. By extension, it is reasonable to speculate that $\mathrm{Hg}^{0}$ in deep water masses also is formed by either an abiotic or microbial reduction process. The difference of $\mathrm{Hg}^{0}$ concentrations in NADW between the western and eastern basins of the North Atlantic may be due to differences in either $\mathrm{Hg}$ reactivity or activity of reductants, including microbes, in the water. Biological reduction of $\mathrm{Hg}$ can be mediated by microbes containing mer-operon encoded proteins (Barkay et al., 2003). While the evolutionary time frame of the mer-operon has not been identified, it is plausible that increasing $\mathrm{Hg}$ in the environment during the past 150 years has exerted selective pressure on the mer operon (Boyd and Barkay, 2012). Accordingly, older NADW may contain less $\mathrm{Hg}^{0}$ due to lower efficiency of microbial $\mathrm{Hg}$ reduction, compared to younger NADW generated during the last 100 years when anthropogenic $\mathrm{Hg}$ emissions were increasing. In contrast, the mer operon may have a much slower evolutionary time scale and the difference in $\mathrm{Hg}^{0}$ between older eastern and younger western NADW may result from a decrease of reducible forms of $\mathrm{Hg}$ after $>100 \mathrm{y}$. Based on the distribution and relatively low concentrations of MMHg and DMHg across the transect, reductive demethylation cannot explain the difference in $\mathrm{Hg}^{0}$ concentrations between basins. 


\subsection{Monomethylmercury}

Monomethylmercury in filtered water ranged from $<0.002$ (detection limit) to $0.60 \mathrm{pM}$ in the North Atlantic Ocean (Table 1). The typical vertical distribution of filtered MMHg at most stations in the North Atlantic was relatively low concentrations in the upper $100 \mathrm{~m}(0.06 \pm 0.05$ $\mathrm{pM}, n=70$ ), a subsurface maximum in the ODZ, and lower concentrations in water below the thermocline (Figure 6a), which is consistent with vertical distributions observed in other ocean basins (Mason and Fitzgerald, 1993; Mason and Sullivan, 1999; Sunderland et al., 2009; Cossa et al., 2009, 2011; Hammerschmidt and Bowman, 2012). Although Hg is methylated in the mixed layer (Lehnherr et al., 2011), relatively low concentrations of MMHg there can be attributed to bioaccumulation and photochemical and microbial decomposition (Monperrus et al., 2007; Lehnherr et al., 2011; Black et al., 2012; Hammerschmidt and Bowman, 2012). As observed for filtered total $\mathrm{Hg}$ and $\mathrm{Hg}^{0}$, filtered $\mathrm{MMHg}$ concentrations in NADW were significantly greater in the western $(0.15 \pm 0.12 \mathrm{pM}, n=31)$ than eastern basin $(0.06 \pm 0.06 \mathrm{pM}, n=64$; Mann-Whitney rank sum, $p<0.001$ ), although there was more intra-basin variability of MMHg concentrations than for the other two Hg species. This comparison of MMHg concentrations in NADW neglects results from Station 16 on the Mid-Atlantic Ridge that has hydrothermal inputs. Some of the variability and greater mean concentration of filtered MMHg in NADW of the western North Atlantic can be attributed to increased concentrations near the slopes of North America and Bermuda, which may result from benthic production and mobilization to overlying water (Hollweg et al., 2010). Aside from these locations, deep ocean sediments do not appear to be an important source of MMHg to the water column of the North Atlantic, as also hypothesized for other ocean basins (Heimbürger et al., 2010; Cossa et al., 2011; Hammerschmidt and Bowman, 
2012). Similar to filtered total $\mathrm{Hg}$, filtered $\mathrm{MMHg}$ in AABW $(0.18 \pm 0.08 \mathrm{pM})$ was increased relative to NADW.

The primary influence on MMHg cycling in the eastern North Atlantic is strong particle scavenging (Figure 6). Scavenging in the eastern Atlantic is evident from both the very low concentrations of filtered MMHg and relatively high levels of particulate MMHg in the mixed layer and permanent thermocline (Figure 6b). Increased particulate MMHg concentrations near the African coast, which are unlike those in the rest of the North Atlantic, are the result of high dust deposition and coastal upwelling that fuel primary production. Given that suspended material had exceedingly low concentrations of MMHg (mean $=0.0007 \pm 0.001 \mathrm{pM})$ and that sinking particles have similar, if not lower, concentrations of MMHg than suspended particles (Lamborg et al, 2009), we would expect release of surface-formed MMHg from sinking particles during remineralization to have little influence on levels of filtered MMHg in the thermocline. Such is the case in the far eastern North Atlantic, where there is no connection between particulate and filtered MMHg. On average, suspended particles contained less than $1 \%$ of total MMHg in the water column.

Subsurface maxima of filtered MMHg were observed in the ODZ across the North Atlantic. Maxima of methylated Hg in ODZs, or oxygen minimum zones, have been widely attributed to in situ production fueled by microbial remineralization of organic matter (Cossa et al., 1994, 2009; Mason \& Fitzgerald, 1993; Mason and Sullivan, 1999; Sunderland et al., 2009; Heimbürger et al., 2010; Hammerschmidt and Bowman, 2012). Multiple sectional oceanographic studies have observed positive associations between concentrations of methylated $\mathrm{Hg}$ and either apparent oxygen utilization (AOU; Mason and Sullivan, 1999; Cossa et al., 1994, 2009, 2011; Kirk et al., 2008; Heimbürger et al., 2010; Lehnherr et al., 2011) or organic carbon 
remineralization rate (Sunderland et al., 2009), which could be interpreted to suggest that production of methylated $\mathrm{Hg}$ in the marine water column is limited by microbial methylation potential more than it is by $\mathrm{Hg}(\mathrm{II})$ availability. However, we observed no correlation between filtered MMHg concentration and either the concentration of dissolved $\mathrm{O}_{2}(p=0.15)$ or AOU $(p$ $=0.42)$ across these far ranging sections of the North Atlantic. The range of AOU along these sections of the North Atlantic $\left(0-227 \mu \mathrm{mol} \mathrm{kg}^{-1}\right)$ is comparable to that of other studies where relationships with MMHg were observed (Mason and Sullivan, 1999; Cossa et al., 2009, 2011; Heimbürger et al., 2010; Sunderland et al., 2009).The absence of a correlation between MMHg and either dissolved $\mathrm{O}_{2}$ or AOU suggests that lower oxygen concentrations and the microbial community, potentially including anaerobes, in the ODZ are not unique in their ability to produce MMHg, which is consistent with results from process studies. Incubation tests with waters from the eastern equatorial Pacific Ocean and Arabian Sea imply that $\mathrm{Hg}(\mathrm{II})$ methylation is not particularly active in oxygen minimum zones and anaerobic microorganisms are not important methylators of $\mathrm{Hg}$ in the marine water column (Malcolm et al., 2010). Moreover, rates of Hg methylation were similar between the oxic mixed layer, near the subsurface chlorophyll maximum, and oxygen minimum zone at multiple locations in the Canadian Arctic Archipelago (Lehnherr et al., 2011). Thus, an alternative hypothesis for the maxima of MMHg in the ODZ is that MMHg may be produced throughout the marine water column and is less susceptible to decomposition and scavenging in the ODZ than it is at other depths. While the functional identities of microorganisms that demethylate MMHg are largely unknown, a slower rate of decomposition in the ODZ is consistent with the inhibitory effect of low $\mathrm{O}_{2}$ concentrations on rates of aerobic metabolism as well as the rarity of mer genes in anaerobic microbes (Barkay et al., 2010). 
Secondary maxima of filtered MMHg also were observed at depths shallower than the ODZ and near the chlorophyll and oxygen maxima at zonal Stations 16-22 in the eastern North Atlantic Ocean (Figure 7). Maxima of filtered MMHg ( 0.2-0.6 pM) were observed between 100-200 $\mathrm{m}$ at these stations and within about $80 \mathrm{~m}$ depth of the in situ fluorescence and associated $\mathrm{O}_{2}$ maxima. Increased $\mathrm{MMHg}$ concentrations immediately below the euphotic zone can be interpreted to indicate production in surface waters and may result from enhanced microbial respiration of organic carbon (Heimbürger et al., 2010).

\subsection{Dimethylmercury}

The distribution of DMHg in the North Atlantic is similar to that of $\mathrm{MMHg}$ and $\mathrm{Hg}^{\mathrm{O}}$ (Figure 8). Like MMHg, concentrations of DMHg in the upper $100 \mathrm{~m}$ were extremely low, increased in the ODZ, and were relatively homogeneous with depth. Low concentrations of DMHg in the mixed layer are a result of its evasion to the atmosphere (Black et al., 2009). Also similar to MMHg, concentrations of DMHg in NADW were considerably greater in the western North Atlantic (mean $=0.18 \pm 0.12 \mathrm{pM}, n=48$ ) than on the east side of the Mid-Atlantic Ridge (mean $=0.07 \pm 0.04 \mathrm{pM}, n=23$; Mann-Whitney rank sum, $p<0.001$ ), excluding results from Station 16 above the ridge. Water deeper than $4000 \mathrm{~m}$, a combination of AABW and NADW, contained $0.18 \pm 0.12 \mathrm{pM}$ of DMHg $(n=16)$, a mean concentration similar to that in western NADW. The average concentration of $\mathrm{\Sigma CH}_{3} \mathrm{Hg}$, calculated as the sum of MMHg and DMHg, in AABW was $0.37 \pm 0.08 \mathrm{pM}$ at stations between 20 and $30^{\circ} \mathrm{N}$, and comparable to, if not slightly

less than, $\Sigma \mathrm{CH}_{3} \mathrm{Hg}$ levels measured in AABW in the Southern Ocean $(0.52 \pm 0.11 \mathrm{pM}$; Cossa et al., 2011). 
Dimethylmercury can be the dominant form of methylated $\mathrm{Hg}$ in the open ocean (Mason and Fitzgerald, 1993; Mason et al., 1995; Mason and Sullivan, 1999). For surface waters in which DMHg was detectable, the filtered MMHg:DMHg molar ratio was large and highly variable in the upper $100 \mathrm{~m}$ of the water column $(18 \pm 25)$. In contrast, MMHg:DMHg averaged $1.6 \pm 1.8$ in North Atlantic water deeper than $1000 \mathrm{~m}$. The filtered MMHg:DMHg ratio for subthermocline waters in the North Atlantic is similar to that in North Pacific Deep and Bottom Waters (> $1500 \mathrm{~m}$ ), which averaged 1.9 \pm 0.4 (Hammerschmidt and Bowman, 2012), and suggests that MMHg is the dominant form of methylated Hg in deep waters. DMHg has been posited to be the immediate product of microbial methylation, with MMHg resulting from its decomposition (Mason and Fitzgerald, 1993; Mason et al., 1995; Mason and Sullivan, 1999). However, results from a recent process study suggest that the rate of MMHg formation from $\mathrm{Hg}(\mathrm{II})$ is about three orders of magnitude greater than production of $\mathrm{DMHg}$ from $\mathrm{Hg}(\mathrm{II})$ in seawater (Lehnherr et al., 2011), implying that DMHg may be formed primarily by methylation of MMHg.

Unlike $\mathrm{Hg}^{0}$ in NADW, which may have been downwelled during deep water formation, DMHg in the water mass was likely formed in situ during thermohaline flow. DMHg concentrations in the mixed layer of the Labrador and Norwegian Seas were either undetectable or less than $0.02 \mathrm{pM}$ (Mason et al., 1998). On the basis of oceanographic measurements and modeling, Mason and Fitzgerald (1993) hypothesized that DMHg accumulates slowly in seawater because its rate of formation and decomposition are of the same order of magnitude. They later observed that DMHg in recently formed NADW increased with age and depth of the water, from about $0.03 \mathrm{pM}$ in the upper water column to $0.13 \pm 0.08 \mathrm{pM}$ at depth at stations between 50 and $60^{\circ} \mathrm{N}$ (Mason et al., 1998). Our results for DMHg in NADW in the western 
Atlantic $(0.18 \pm 0.12 \mathrm{pM})$ are consistent with this hypothesis and suggest that concentrations may have increased during southward transit between 50 and $60{ }^{\circ} \mathrm{N}$ to between 25 and $40{ }^{\circ} \mathrm{N}$ in the current study. However, the lower concentrations of DMHg in NADW of the eastern compared to the western basin are inconsistent with the hypothesis. Indeed, levels of both $\mathrm{DMHg}$ and filtered MMHg were significantly lower in older eastern than younger western NADW. The mean concentration of DMHg in western NADW was 2.6-fold greater than that in the eastern basin and the average level of MMHg in the west was 2.5-fold greater than in eastern NADW. The similarity of these enrichment factors indicates that concentrations of filtered MMHg and DMHg are proportional in NADW on both sides of the Mid-Atlantic Ridge. However, the difference between these enrichment factors and that of filtered total $\mathrm{Hg}$ in NADW (1.14-fold greater in the west), suggests that older NADW has less of a methylation potential for $\mathrm{Hg}$ than younger deep water in the west. This is supported by the mean fraction of total $\mathrm{Hg}$ as $\mathrm{MMHg}$ in filtered water being significantly greater in western NADW $(14 \pm 11 \%)$ than in eastern NADW $(7 \pm 8 \%$; Mann-Whitney rank sum, $p<0.01)$. A difference in the average percentage of filtered total $\mathrm{Hg}$ as $\Sigma \mathrm{CH}_{3} \mathrm{Hg}$ in NADW also existed between the western $(33 \pm 16 \%)$ and eastern $(23 \pm$ $14 \%)$ North Atlantic but the difference was not significant at $\alpha=0.05$ ( $t$-test, $p=0.08$ ).

\subsection{TAG hydrothermal vent plume}

Seawater and suspended particles were sampled from a plume at the TAG submarine hydrothermal vent mound located on the east wall of the Mid-Atlantic Ridge (Station 16, 26.14 ${ }^{\circ} \mathrm{N}, 44.83{ }^{\circ} \mathrm{W}$; Rona et al., 1986). The buoyant plume was located between 3200 and $3400 \mathrm{~m}$ depth and identified during sampling with a transmissometer. Previous studies of vent systems in the Pacific Ocean have found a wide range of total $\mathrm{Hg}$ concentrations in hydrothermal vent fluids 
(4-11,000 pM; Lamborg et al., 2006; Crespo-Medina et al., 2009) although little is known about $\mathrm{Hg}$ in vent systems of the Atlantic Ocean (Demina et al., 2012).

Mercury is emitted from the TAG hydrothermal vent and $\mathrm{Hg}$ species are scavenged and transformed in the plume (Figures 3 and 9). The maximum concentration of filtered total $\mathrm{Hg}$ in the plume was $13 \mathrm{pM}$ at $3400 \mathrm{~m}$ depth, more than $10 \times$ greater than levels in surrounding NADW (Figure 9a). The speciation of $\mathrm{Hg}$ at the filtered total $\mathrm{Hg}$ maximum (3400 m depth) was $8 \%$ as $\mathrm{Hg}^{0}, 3 \%$ as filtered $\mathrm{MMHg}$, and less than $0.2 \%$ as $\mathrm{DMHg}$, with particulate $\mathrm{Hg}$ comprising less than $2 \%$ of the total $\mathrm{Hg}$. This speciation is in contrast to vent fluids sampled at the Gorda Ridge in the Pacific Ocean where nearly all $\mathrm{Hg}$ was present as MMHg (Lamborg et al., 2006). At shallower depths in the TAG plume (3200-3330 m), filtered total $\mathrm{Hg}$ decreased to $0.90 \pm 0.04$ $\mathrm{pM}$, concentrations less than those in NADW above the plume (1.15 pM), and $\mathrm{Hg}^{0}$ decreased to $0.13 \pm 0.06 \mathrm{pM}$ and as low as $0.05 \mathrm{pM}$ at $3250 \mathrm{~m}$ (Figure 9a), a concentration 8-fold less than in NADW above the plume and 20 -fold less than at $3400 \mathrm{~m}$. The decline of filtered total $\mathrm{Hg}$ between the bottom and interior of the plume can be attributed to scavenging. Metal oxides are formed within the plume and concentrations of particulate total $\mathrm{Hg}$ follow those of particulate $\mathrm{Fe}$ oxides, with $27 \%$ of the total $\mathrm{Hg}$ at $3300 \mathrm{~m}$ depth being associated with particles (Figure $9 \mathrm{~b}$ ). Because $\mathrm{Hg}^{0}$ is not particle reactive, its loss from the core of the hydrothermal plume may result from oxidation reactions.

The TAG hydrothermal vent also was a localized source of MMHg, but not DMHg, to the deep North Atlantic (Figure 9). MMHg was enriched in the hydrothermal plume relative to waters above and below. In contrast to total $\mathrm{Hg}$ that was reactive to particle scavenging, more than $99.5 \%$ of MMHg in the plume was in the filtered phase, resulting in MMHg accounting for $42 \pm 24 \%$ of filtered total $\mathrm{Hg}$ in the plume at depths other than the filtered total $\mathrm{Hg}$ maximum at 
$3400 \mathrm{~m}$. Particle-water partitioning coefficients of MMHg are typically an order of magnitude less than those of $\mathrm{Hg}(\mathrm{II})$ in oxic seawater (Balcom et al., 2008). The apparent absence of any DMHg enrichment in the hydrothermal plume is consistent with DMHg being less stable at higher temperatures (Mason and Sullivan, 1999) and lower pH (Wood et al., 1968; Beijer and Jernelöv, 1979) than would expected in the vent. While the source of MMHg in submarine hydrothermal fluids is unknown and may be either biological or abiotic (Lamborg et al., 2006), the two gene clusters associated with bacterial Hg methylation (Parks et al., 2013) have been identified in at least one species of hydrothermal vent bacteria, Deferrisoma camini (Slobodkina et al., 2012).

\section{Summary}

The U.S. GEOTRACES zonal and meridional sections of the North Atlantic Ocean have allowed for the first fully resolved high-resolution examination of $\mathrm{Hg}$ speciation within this basin. We found that filtered total $\mathrm{Hg}, \mathrm{MMHg}, \mathrm{Hg}^{0}$, and DMHg in water of the North Atlantic are vertically segregated as a function of bioaccumulation, scavenging, remineralization, and transformation reactions in the water column. A hydrothermal vent on the Mid-Atlantic Ridge was confirmed to be a source of total $\mathrm{Hg}$ and MMHg to deep water, as suggested by previous studies of vent fluids elsewhere. Our most significant and unexpected discovery was the horizontal segregation of $\mathrm{Hg}$ and its chemical species in NADW between the western and eastern North Atlantic. While greater concentrations of filtered total $\mathrm{Hg}$ in younger NADW of the western basin compared to the eastern North Atlantic may be attributed to younger NADW having downwelled anthropogenic Hg during deep water formation (Lamborg et al., accepted), 
the reason for horizontal enrichment of $\mathrm{Hg}^{0}, \mathrm{MMHg}$, and DMHg in western NADW is unknown. We speculate that younger NADW has a greater methylation and reduction potential than older waters in the mass. Both a meridional section of the western North Atlantic as well as processbased investigations are needed to better understand the enrichment of $\mathrm{Hg}^{0}, \mathrm{MMHg}$, and $\mathrm{DMHg}$ in western NADW.

\section{Acknowledgements}

We thank our U.S. GEOTRACES colleagues, especially co-chief scientists Greg Cutter, Ed Boyle, and Bob Anderson. Jessica Fitzsimmons, Peter Morton, Randie Bundy, Rachel Shelley, and Anna Aguilar-Islas helped sample and filter water. Phoebe Lam and Dan Ohnemus sampled suspended particles and provided particulate Fe data for the hydrothermal plume. This research was supported by the U.S. National Science Foundation Chemical Oceanography Program. 


\section{References}

Amos, H.M., Jacob, D.J., Streets, D.G., Sunderland, E.M. 2013. Legacy impacts of all-time anthropogenic emissions on the global mercury cycle. Global Biogeochem. Cycles 27, 410-421.

Antia, A.N., Koeve, W., Fischer, G., Blanz, T., Schulz-Bull, D., Scholten, J., Neuer, S., Kremling, K., Kuss, J., Peinert, R., Hebbeln, D., Bathmann, U., Conte, M., Fehner, U., Zeitzschel, B. 2001. Basin-wide particulate carbon flux in the Atlantic Ocean: regional export patterns and potential for atmospheric $\mathrm{CO}_{2}$ sequestration. Global Biogeochem. Cycles 15, 845-862.

Andersson, M.E., Sommar, J., Gårdfeldt, K., Lindqvist, O. 2008. Enhanced concentrations of dissolved gaseous mercury in the surface waters of the Arctic Ocean. Mar. Chem. 110, $190-194$.

Andersson, M.E., Sommar, J., Gårdfeldt, K., Jutterstr m, S. 2011. Air-sea exchange of volatile mercury in the North Atlantic Ocean. Mar. Chem. 125, 17.

Balcom, P.H., Fitzgerald, W.F., Vandal, G.M., Lamborg, C.H., Rolfhus, K.R., Langer, C.S., Hammerschmidt, C.R. 2004. Mercury sources and cycling in the Connecticut River and Long Island Sound. Mar. Chem. 90, 53-74.

Balcom, P.H., Hammerschmidt, C.R., Fitzgerald, W.F., Lamborg, C.H., O’Connor, J.S. 2008. Seasonal distributions and cycling of mercury and methylmercury in the waters of New York/New Jersey Harbor Estuary. Mar. Chem. 109, 1-17.

Barkay, T., Miller, S.M., Summers, A.O. 2003. Bacterial mercury resistance from atoms to ecosystems. FEMS Microbiol. Rev. 27, 355384. 
Barkay, T., Kritee, K., Boyd, E., Geesey, G. 2010. A thermophilic bacterial origin and subsequent constraints by redox, light and salinity on the evolution of the microbial mercuric reductase. Environ. Microbiol. 12, 2904-2917.

Beijer, K., Jernelöv, A. 1979. Methylation of mercury in aquatic environments. In The biogeochemistry of mercury in the environment, J. Nriagu, Ed. Elsevier, Amsterdam.

Bishop, J.K.B., Lam, P.J., Wood, T.J. 2012. Getting good particles: Accurate sampling of particles by large volume in-situ filtration. Limnol. Oceanogr.: Methods 10, 681710.

Black, F.J., Conaway, C.H., Flegal, A.R. 2009. Stability of dimethylmercury in seawater and its conversion to monomethyl mercury. Environ. Sci. Technol. 43, 4056-4062.

Black, F.J., Poulin, B.A., Flegal, A.R. 2012. Factors controlling the abiotic photo-degradation of monomethylmercury in surface waters. Geochim. Cosmochim. Acta 84, 492-507.

Bloom, N.S. 1989. Determination of pictogram levels of methylmercury by aqueous phase ethylation, followed by cryogenic gas chromatography, with cold vapour atomic fluorescence detection. Can. J. Fish. Aquat. Sci. 46, 11311140.

Bloom, N.S., Fitzgerald, W.F. 1988. Determination of volatile mercury species at the picogram level by low-temperature gas chromatography with cold-vapor atomic fluorescence detection. Anal. Chim. Acta. 208, 151161.

Bose-O'Reilly, S., McCarty, K.M., Steckling, N., Lettmeier, B. 2010. Mercury exposure and children's health. Curr. Probl. Pediatr. Adolesc. Health Care 40, 186215.

Bowman, K.L., Hammerschmidt, C.R. 2011. Extraction of monomethylmercury from seawater for low-femtomolar determination. Limnol. Oceanor-Meth. 9, 121128.

Boyd, E.S., Barkay, T. 2012. The mercury resistance operon: from an origin in a geothermal environment to an efficient detoxification machine. 3, 349 . 
Broecker, W.S., Blanton, S., Smethie, W., Ostlund, G. 1991. Radiocarbon decay and oxygen utilization in the deep Atlantic Ocean. Global Biogeochem. Cycles 5, 87117.

Cossa, D., Martin, J-M. Sanjuan, J. 1994. Dimethylmercury formation in the Alboran Sea. Mar. Pollut. Bull. 28, 381-384.

Cossa, D., Averty, B., Pirrone, N. 2009. The origin of methylmercury in open Mediterranean waters. Limnol. Oceanogr. 53, 837-844.

Cossa, D., Heimbürger, L.-E., Lannuzel, D., Rintoul, S.R., Butler, E.C.V., Bowie, A.R., Averty, B., Watson, R.J., Remenyi, T. 2011. Mercury in the Southern Ocean. Geochim. Cosmochim. Ac. 75, 40374052.

Costa, M., Liss, P.S. 1999. Photoreduction of mercury in sea water and its possible implications for $\mathrm{Hg}^{0}$ air-sea fluxes. Mar. Chem. 68, 87-95.

Crespo-Medina, M., Chatziefthimiou, A.D., Bloom, N.S., Luther III, G.W., Wright, D.D., Reinfelder, J.R., Vetriani, C., Barkay, T. 2009. Adaptation of chemosynthetic microorganisms to elevated mercury concentrations in deep-sea hydrothermal vents. Limnol. Oceanogr. 54, 4149.

Cutter, G.A., Bruland, K.W. 2012. Rapid and noncontaminating sampling system for trace elements in global ocean surveys. Limnol. Oceanogr-Meth. 10, 425430.

Demina, L.L., Holm, N.G., Galkin, S.V., Lein, A.Y. 2013. Some features of the trace metal biogeochemistry in the deep-sea hydrothermal vent fields (Menez Gwen, Rainbow, Broken Spur at the MAR and $9^{\circ} 50^{\prime} \mathrm{N}$ at the EPR): A synthesis. J. Marine Syst. 126, 94105. 
Ebinghaus, R., Jennings, S.G., Kock, H.H., Derwent, R.G., Manning, A.J., Spain, T.G. 2011. Decreasing trends in total gaseous mercury observations in baseline air at Mace Head, Ireland from 1996 to 2009. Atmos. Environ. 45, 3475-3480.

Fitzgerald, W.F., Gill, G.A. 1979. Subnanogram determination of mercury by two-stage gold amalgamation applied to atmospheric analysis. Anal. Chem. 51, 17141720.

Fitzgerald, W.F., Engstrom, D.R., Mason, R.P., Nater, E.A. 1998. The case from atmospheric mercury contamination in remote areas. Environ. Sci. Technol. 32, 17.

Fitzgerald, W.F., Lamborg, C.H., Hammerschmidt, C.R. 2007. Marine biogeochemical cycling of mercury. Chem. Rev. 107, 641662.

Hammerschmidt, C.R. 2011. Mercury and carbon dioxide relationships: Uncoupling a toxic relationship. Environ. Toxicol. Chem. 30, 26402646.

Hammerschmidt, C.R., Bowman, K.L. 2012. Vertical methylmercury distribution in the subtropical North Pacific Ocean. Mar. Chem. 132 133, 7782.

Hammerschmidt, C.R., Fitzgerald, W.F. 2006a. Methylmercury cycling in sediments on the continental shelf of southern New England. Geochim. Cosmochim. Acta 70, 918-930.

Hammerschmidt, C.R., Fitzgerald, W.F. 2006b. Bioaccumulation and trophic transfer of methylmercury in Long Island Sound. Arch. Environ. Contam. Toxicol. 51, 416424.

Hammerschmidt, C.R., Bowman, K.L., Tabatchnick, M.D., Lamborg, C.H. 2011. Storage bottle material and cleaning for determination of total mercury in seawater. Limnol. OceanogrMeth. 9, 426431.

Heimbüger, L.-E., Cossa, D., Marty, J.-C., Migon, C., Averty, B., Dufour, A., Ras, J. 2010. Methyl mercury distributions in relation to the presence of nano- and picophytoplankton 
in an oceanic water column (Ligurian Sea, North-western Mediterranean). Geochim. Cosmochim. Acta 74, 55495559.

Hollweg, T.A., Gilmour, C.C., Mason, R.P. 2010. Mercury and methylmercury cycling in sediments of the mid-Atlantic continental shelf and slope. Limnol. Oceanogr. 55, 27032722.

Jenkins, W.J., Smethie, W.M., Boyle, E.A., Cutter, G.C. In review. Water mass analysis for the U.S. GEOTRACES North Atlantic sections.

Kirk, J.L., St. Louis, V.L., Hintelmann, H., Lehnherr, I., Else, B., Poissant, L. 2008. Methylated mercury species in marine waters of the Canadian High and Sub Arctic. Environ. Sci. Technol. 42, 8367-8373.

Kocman, D., Horvat, M., Pirrone, N., Cinnirella, S. 2013. Contribution of contaminated sites to the global mercury budget. Environ. Res. 125, 160-170.

Lamborg, C.H., Von Damm K.L., Fitzgerald, W.F., Hammerschmidt, C.R., Zierenberg, R. 2006. Mercury and monomethylmercury in fluids from Sea Cliff submarine hydrothermal field, Gorda Ridge. Geophys. Res. Lett. 33, L17606.

Lamborg, C.H., Hammerschmidt, C.R., Saito, M.A., Goepfert, T.J., Lam, P.J. 2009. Mercury methylation in the gyre and Benguela upwelling regions of the South Atlantic Ocean. $9^{\text {th }}$ International Conference on Mercury as a Global Pollutant, Guiyang, China.

Lamborg, C.H., Hammerschmidt, C.R., Gill, G.A., Mason, R.P., Gichuki, S. 2012. An intercomparison of procedures for the determination of total mercury in seawater and recommendations regarding mercury speciation during GEOTRACES cruises. Limnol. Oceanogr-Meth. 10, 90100. 
Lamborg, C.H., Hammerschmidt, C.R., Bowman, K.L., Swarr, G., Munson, K.M., Rijkenberg, M., Saito, M.A. In press. Anthropogenic mercury in the ocean estimated from water column measurements. Nature.

Lehnherr, I., St. Louis, V.L., Hintelmann, H., Kirk, J.L. 2011. Methylation of inorganic mercury in polar marine waters. Nat. Geosci. 4, 298302.

Malcom, E.G., Schaefer, J.K., Ekstrom, E.B., Tuit, C.B., Jayakumar, A., Park, H., Ward, B.B., Morel, F.M.M. 2010. Mercury methylation in oxygen deficient zones of the oceans: No evidence for the predominance of anaerobes. Mar. Chem. 122, 1119.

Mason, R.P, Fitzgerald, W.F. 1993. The distribution and biogeochemical cycling of mercury in the equatorial Pacific Ocean. Deep-Sea Res. I 40, 18971924.

Mason, R.P., Sullivan, K.A. 1999. The distribution and speciation of mercury in the South and equatorial Atlantic. Deep-Sea Res. II 46, 937956.

Mason, R.P., Rolfhus, K.R., Fitzgerald, W.F. 1995. Methylated and elemental mercury cycling in surface and deep ocean waters of the North Atlantic. Water Air Soil Pollut. 80, 665677.

Mason, R.P., Rolfhus, K.R., Fitzgerald, W.F. 1998. Mercury in the North Atlantic. Mar. Chem. $61,3753$.

Mason, R.P., Choi, A.L., Fitzgerald, W.F., Hammerschmidt, C.R., Lamborg, C.H., Soerensen, A.L., Sunderland, E.M. 2012. Mercury biogeochemical cycling in the ocean and policy implications. Environ. Res. 119, 101117.

Monperrus, M., Tessier, E., Amouroux, D., Leynaert, A., Huonnic, P., Donard, O.F.X. 2007. Mercury methylation, demethylation and reduction rates in coastal and marine surface waters of the Mediterranean Sea. Mar. Chem. 107, 4963. 
NOAA (National Oceanic and Atmospheric Administration). Table of Global Hydrothermal Vents. http://www.pmel.noaa.gov/vents/PlumeStudies/global-vents/global-ventstext.html.

NOAA (National Oceanic and Atmospheric Administration). 2006. 2-minute gridded global relief data (ETOPO2v2). http://www.ngdc.noaa.gov/mgg/global/etopo2.html

Parks, J.M., Johs, A., Podar, M., Bridou, R., Hurt Jr., R.A., Smith, S.D., Tomanicek, S.J., Qian, Y., Brown, S.D., Brandt, C.C., Palumbo, A.V., Smith, J.C., Wall, J.D., Elias, D.A., Liang, L. 2013. The genetic basis for bacterial mercury methylation. Science 339, 13321335.

Pirrone, N., Cinnirella, S., Feng, X., Finkelman, R.B., Friedli, H.R., Leaner, J., Mason, R., Mukherjee, A.B., Stracher, G.B., Streets, D.G., Telmer, K. 2010. Global mercury emissions to the atmosphere from anthropogenic and natural sources. Atmos. Chem. Phys. 10, 59515964.

Poulain, A.J., Chadhain, S.M.N., Ariya, P.A., Amyot, M., Garcia, E., Campbell, P.G.C., Zylstra, G.J., Barkay, T. 2007. Potential for mercury reduction by microbes in the high Arctic. Appl. Environ. Microbiol. 73, 2230-2238.

Rolfhus, K.R., Fitzgerald, W.F. 2004. Mechanisms and temporal variability of dissolved gaseous mercury production in coastal seawater. Mar. Chem. 90, 125-136.

Rona, P.A., Klinkhammer, G., Nelsen, T.A., Trefry, J.H., Elderfield, H. 1986. Black smokers, massive sulfides and vent biota at the Mid-Atlantic Ridge. Nature 321, 3337.

Scheuhammer, A.M., Meyer, M.W., Sandheinrich, M.B., Murray, M.W. 2007. Effects of environmental methylmercury on the health of wild birds, mammals, and fish. Ambio. $36,1218$. 
Slobodkina, G.B., Reysenbach, A.-L., Panteleeva, A.N., Kostrikina, N.A., Wagner, I.D., BonchOsmolovskaya, E.A., Slobodkin, A.I. 2012. Deferrisoma camini gen. nov., sp. nov., a moderately thermophilic, dissimilatory iron (III)-reducing bacterium from a deep-sea hydrothermal vent that forms a distinct phylogenetic branch in the Deltaproteobacteria. Int. J. Syst. Evol. Micr. 62, 2463.

Streets, D.G., Zhang, W., Wu, Ye. 2009. Projections of global mercury emissions in 2050. Environ. Sci. Technol. 43, 29832988.

Sunderland, E. M. 2007. Mercury exposure from domestic and imported estuarine and marine fish in the U.S. seafood market. Environ. Health Perspect. 115, 235242.

Sunderland, E.M., Krabbenhoft, D.P., Moreau, J.W., Strode, S.A., Landing, W.A. 2009. Mercury sources, distribution, and bioavailability in the North Pacific Ocean: Insights from data and models. Global Biogeochem. Cycles 23, GB2010.

Tseng, C.-M., Hammerschmidt, C.R., Fitzgerald, W.F. 2004. Determination of methylmercury in environmental matrixes by on-line flow injection and atomic fluorescence spectrometry. Anal. Chem. 76, 71317136.

Višnjevec, A.M., Kocman, D., Horvat. M. 2014. Human mercury exposure and effects in Europe. Environ. Toxicol. Chem. 33, 1259-1279.

Whalin, L., Kim, E.-H., Mason, R. 2007. Factors influencing the oxidation, reduction, methylation and demethylation of mercury species in coastal waters. Mar. Chem. 107, $278-294$.

Wood, J.M., Kennedy, F.S., Rosen, C.G. 1968. Synthesis of methyl-mercury compounds by extracts of a methanogenic bacterium. Nature 220, 173-174. 
Zahir, F., Rizwi, S.J., Haq, S.K., Khan, R.H. 2005. Low dose mercury toxicity and human health. Environ. Toxicol. Pharmacol. 20, 351360. 
Table 1. Summary of $\mathrm{Hg}$ species concentrations including results from all stations and depths.

For suspended particulate $\mathrm{MMHg}$, the percentage of total $\mathrm{Hg}$ is referenced to only the suspended particulate phase.

\begin{tabular}{lcccc}
\hline $\mathrm{Hg}$ species & Mean $\pm \mathrm{SD}(\mathrm{pM})$ & Range $(\mathrm{pM})$ & \% of total Hg & $n$ \\
\hline Filtered total $\mathrm{Hg}^{\mathrm{a}}$ & $0.89 \pm 0.30$ & $0.09-1.89$ & -- & 605 \\
$\mathrm{Hg}^{0}$ & $0.31 \pm 0.16$ & $0.01-0.84$ & $35 \pm 16$ & 600 \\
$\mathrm{DMHg}$ & $0.095 \pm 0.10$ & $<\mathrm{DL}-0.65$ & $10 \pm 11$ & 427 \\
Filtered MMHg & $0.095 \pm 0.098$ & $<\mathrm{DL}-0.60$ & $11 \pm 11$ & 432 \\
Particulate total Hg & $0.038 \pm 0.039$ & $<\mathrm{DL}-0.38$ & -- & 322 \\
Particulate MMHg & $0.00069 \pm 0.0013$ & $<\mathrm{DL}-0.010$ & $3 \pm 6$ & 255 \\
\hline
\end{tabular}

${ }^{\mathrm{a}}$ Results from the TAG hydrothermal vent plume at Station 16 are not included in the summary for filtered total $\mathrm{Hg}$. 


\section{Figure captions}

Figure 1. GEOTRACES GA03 water sampling stations during the meridional (red) and zonal (yellow) sections of the North Atlantic Ocean. Stations occupied in 2010 are indicated by diamonds, and stations occupied in 2011 are indicated by circles.

Figure 2. Water masses in the North Atlantic along the GEOTRACES GA03 transect, superimposed on the salinity distribution. Surface waters are mainly North Atlantic Central Water (NACW) with Atlantic Equatorial Water (AEW) at the southernmost extent of the cruise near the Cape Verde Islands. Intermediate waters include Irminger Sea Water (ISW) in the west, Antarctic Intermediate Water (AAIW) near the Cape Verde Islands, and Mediterranean Overflow Water (MOW) in the east. North Atlantic Deep Water (NADW) is between 1500 and $\sim 4000 \mathrm{~m}$. Water deeper than $4000 \mathrm{~m}$ is a mixture of NADW and Antarctic Bottom Water (AABW) with the fraction as $\mathrm{AABW}$ increasing below $5000 \mathrm{~m}$ (Jenkins et al., in review). Sampling points are shown as black dots and station numbers are listed intermittently throughout the grey bathymetric section.

Figure 3. Distribution of total Hg concentrations (pM) in filtered water (panel A) and suspended particles (panel B) along GEOTRACES GA03 in the North Atlantic Ocean. Isobars of dissolved oxygen have concentration units of $\mu \mathrm{mol} / \mathrm{kg}$. Sampling points are shown as black dots and station numbers are listed intermittently throughout the grey bathymetric sections. 
Figure 4. Distribution of $\mathrm{Hg}^{0}(\mathrm{pM})$ along GEOTRACES GA03 in the North Atlantic Ocean. Isobars of dissolved oxygen have concentration units of $\mu \mathrm{mol} / \mathrm{kg}$. Sampling points are shown as black dots and station numbers are listed intermittently throughout the grey bathymetric section.

Figure 5. Vertical profiles of elemental Hg (grey circles), filtered total Hg (black circles), nitrate (open triangles), and dissolved oxygen (dashed line) at zonal Stations 12 (panel A) and 20 (panel B) of GEOTRACES GA03 in the North Atlantic Ocean. Error bars are covered by figure symbols; relative percent difference was $4 \pm 4(n=5)$ for filtered total $\mathrm{Hg}$, and $0.3 \pm 0.7(n=72)$ for nitrate.

Figure 6. Distribution of $\mathrm{MMHg}$ concentrations $(\mathrm{pM})$ in filtered water (panel A) and suspended particles (panel B) along GEOTRACES GA03 in the North Atlantic Ocean. Isobars of dissolved oxygen have concentration units of $\mu \mathrm{mol} / \mathrm{kg}$. Sampling points are shown as black dots and station numbers are listed intermittently throughout the grey bathymetric sections.

Figure 7. Profiles of filtered MMHg (closed circles), CTD fluorescence (solid line), and dissolved $\mathrm{O}_{2}$ (dashed line) at zonal Stations 16-18 near the center of the North Atlantic Ocean. The grey area highlights MMHg maxima in oxic water between 100 and $200 \mathrm{~m}$ depth.

Figure 8. Distribution of DMHg concentrations (pM) along GEOTRACES GA03 in the North Atlantic Ocean. Isobars of dissolved oxygen have concentration units of $\mu \mathrm{mol} / \mathrm{kg}$. Sampling points are shown as black dots and station numbers are listed intermittently throughout the grey bathymetric section. 
Figure 9. Filtered total $\mathrm{Hg}$ and $\mathrm{Hg}^{0}$ (panel A), particulate $\mathrm{Hg}$ and iron (panel B), and filtered MMHg and DMHg in the TAG hydrothermal vent plume (zonal Station 16). The grey area highlights the layer of the hydrothermal plume between 3200 and $3400 \mathrm{~m}$ depth. 
Figure 1

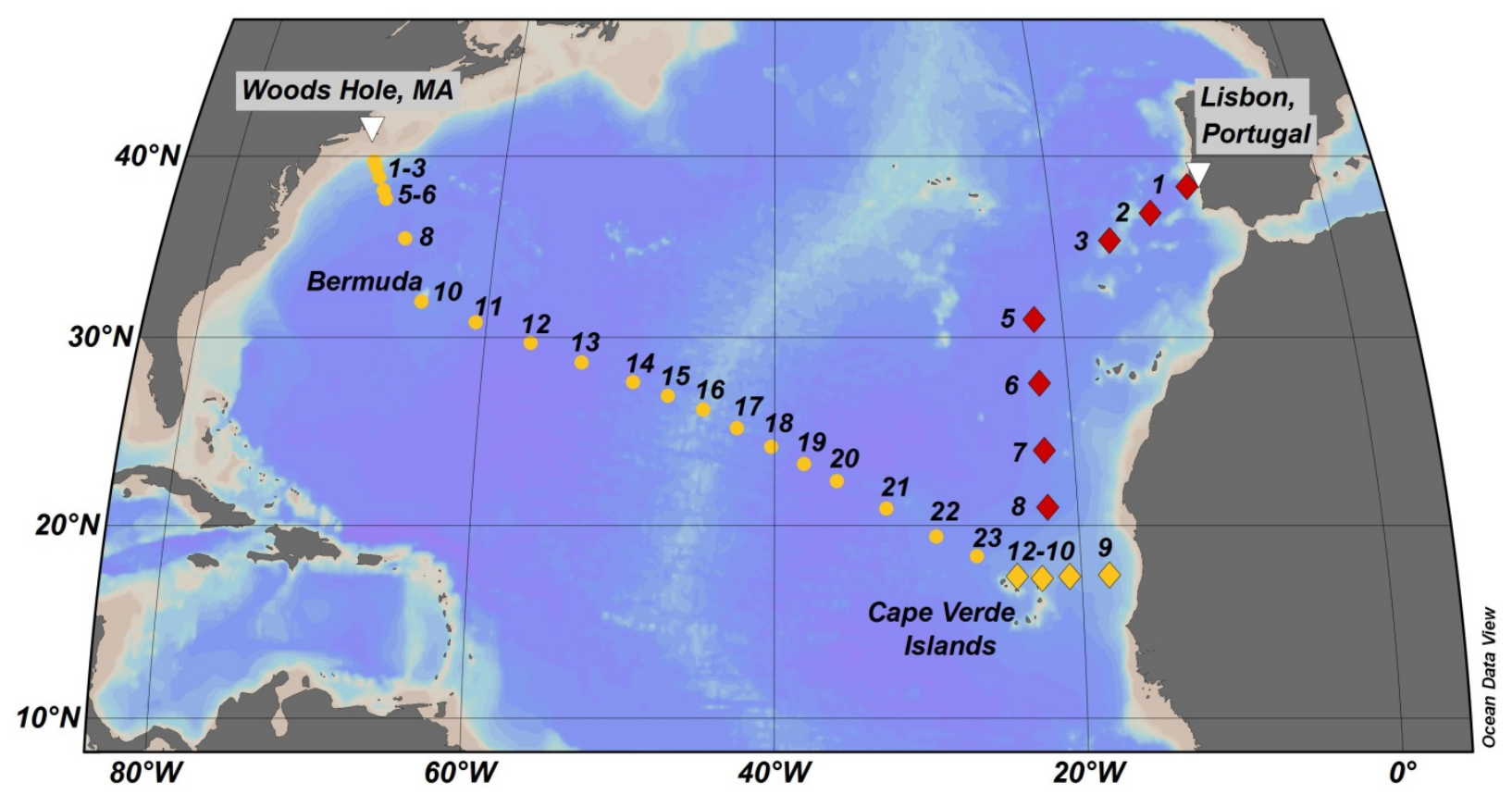


Figure 2

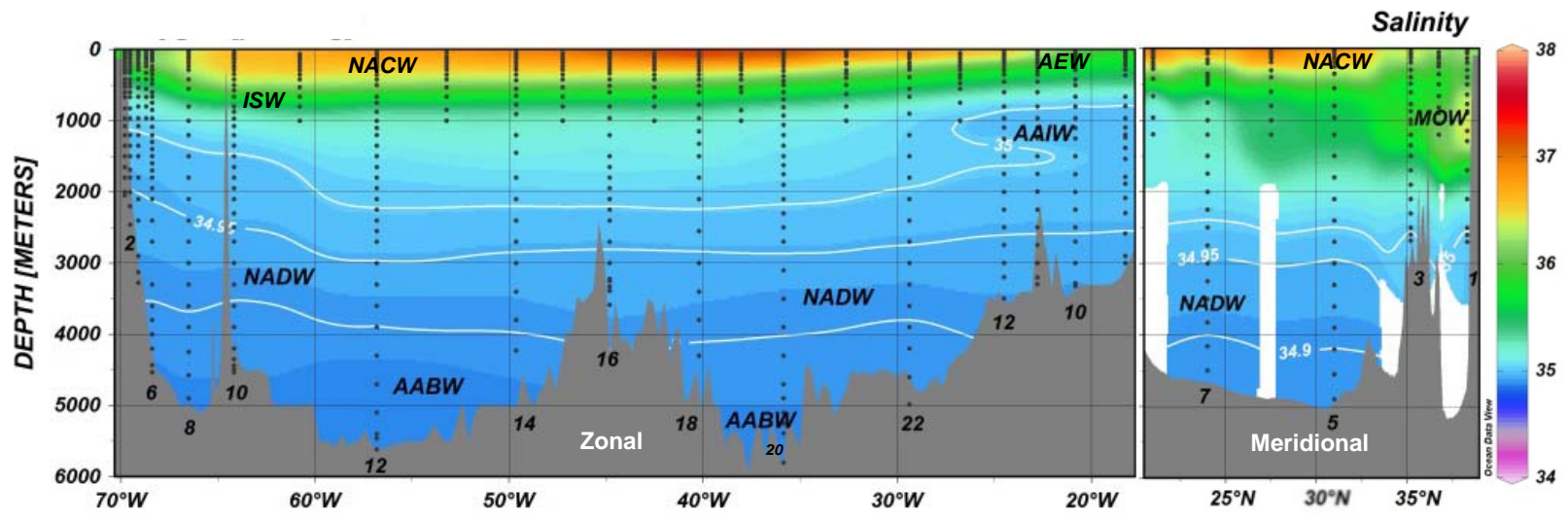


Figure 3

A
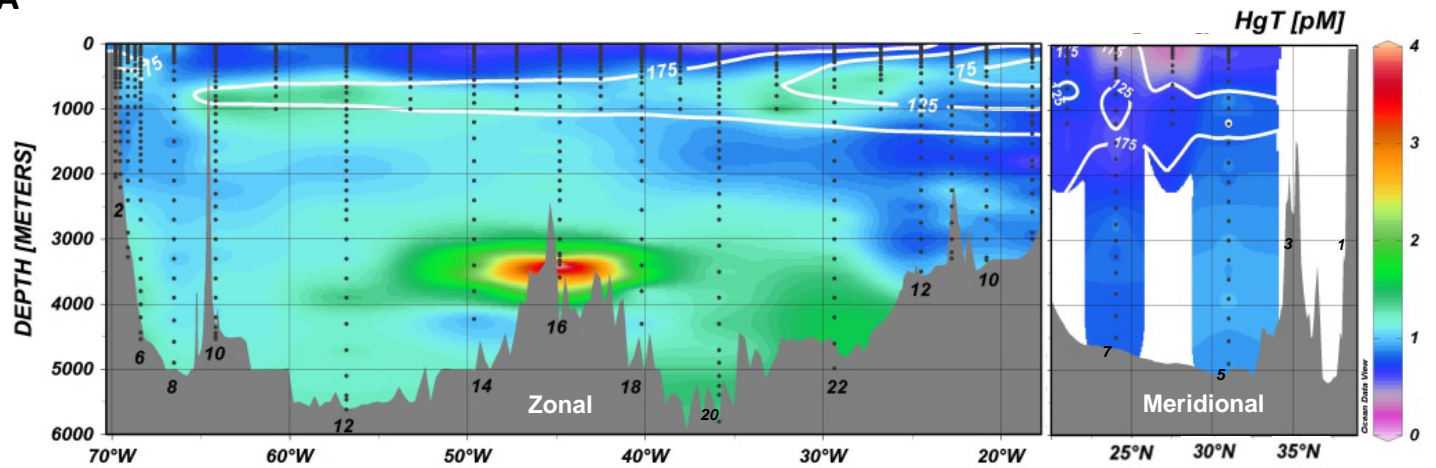

B

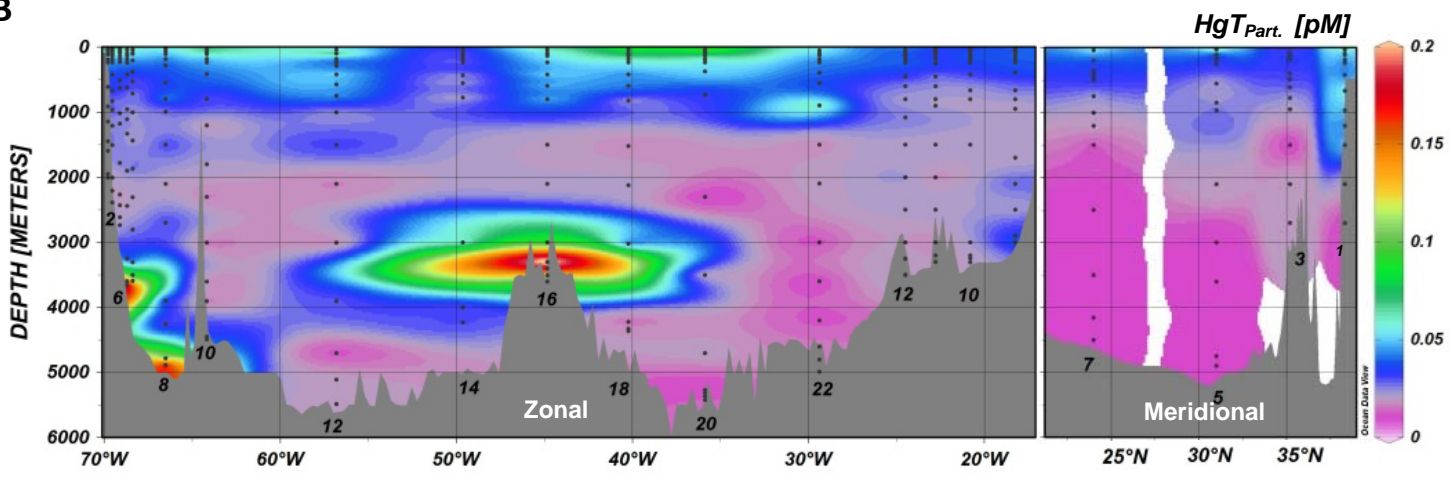


Figure 4

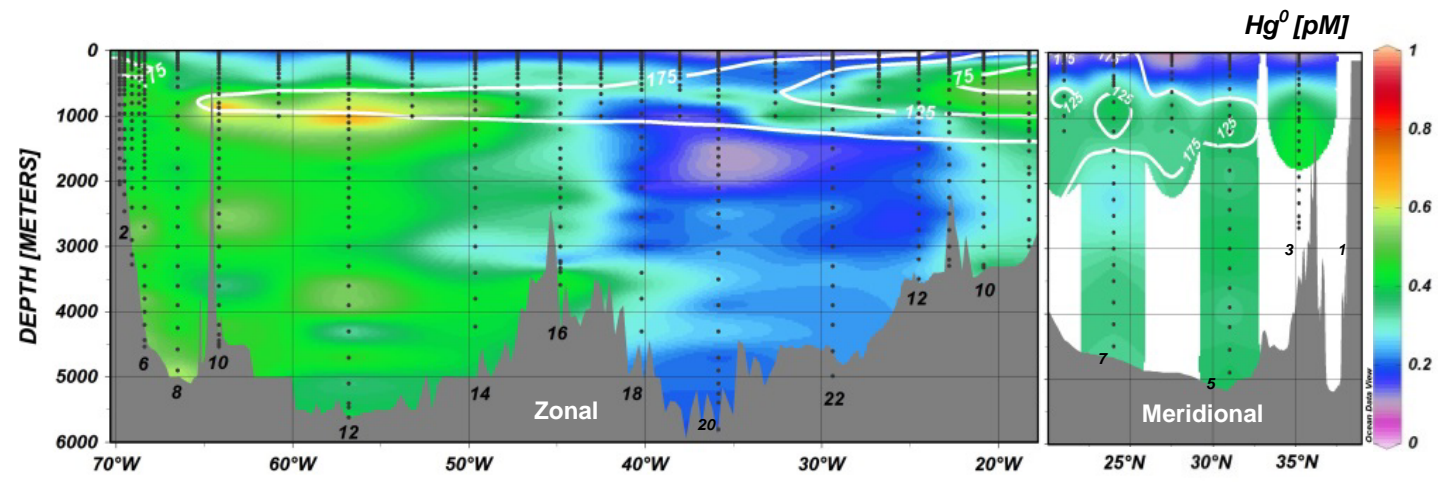


Figure 5

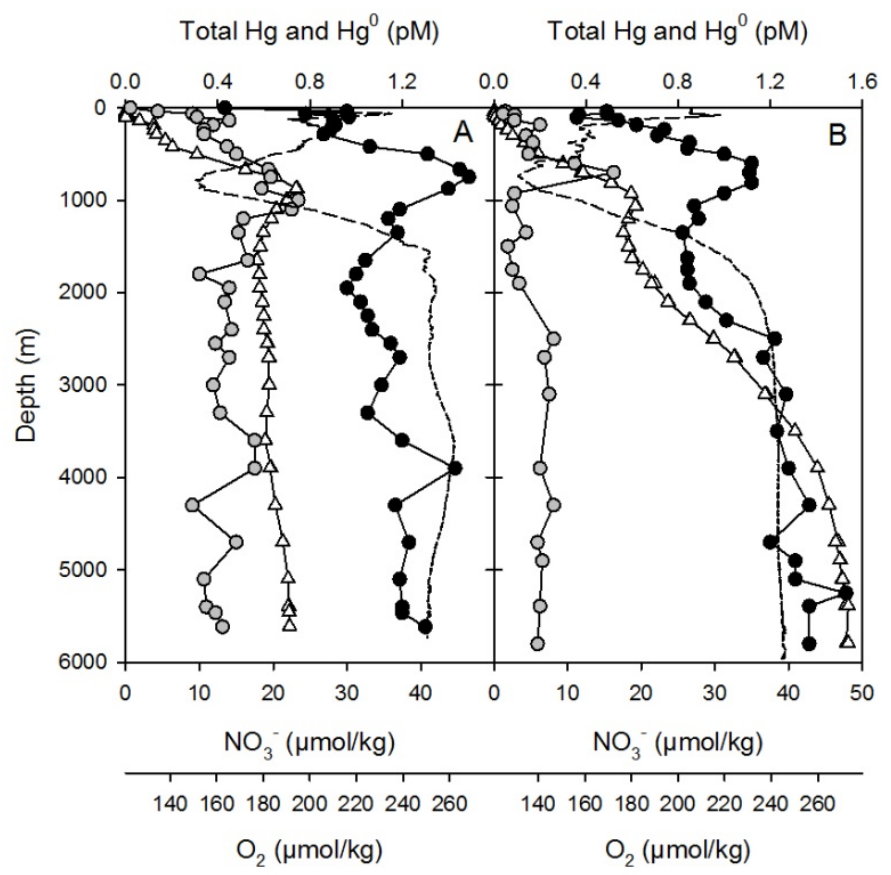


Figure 6
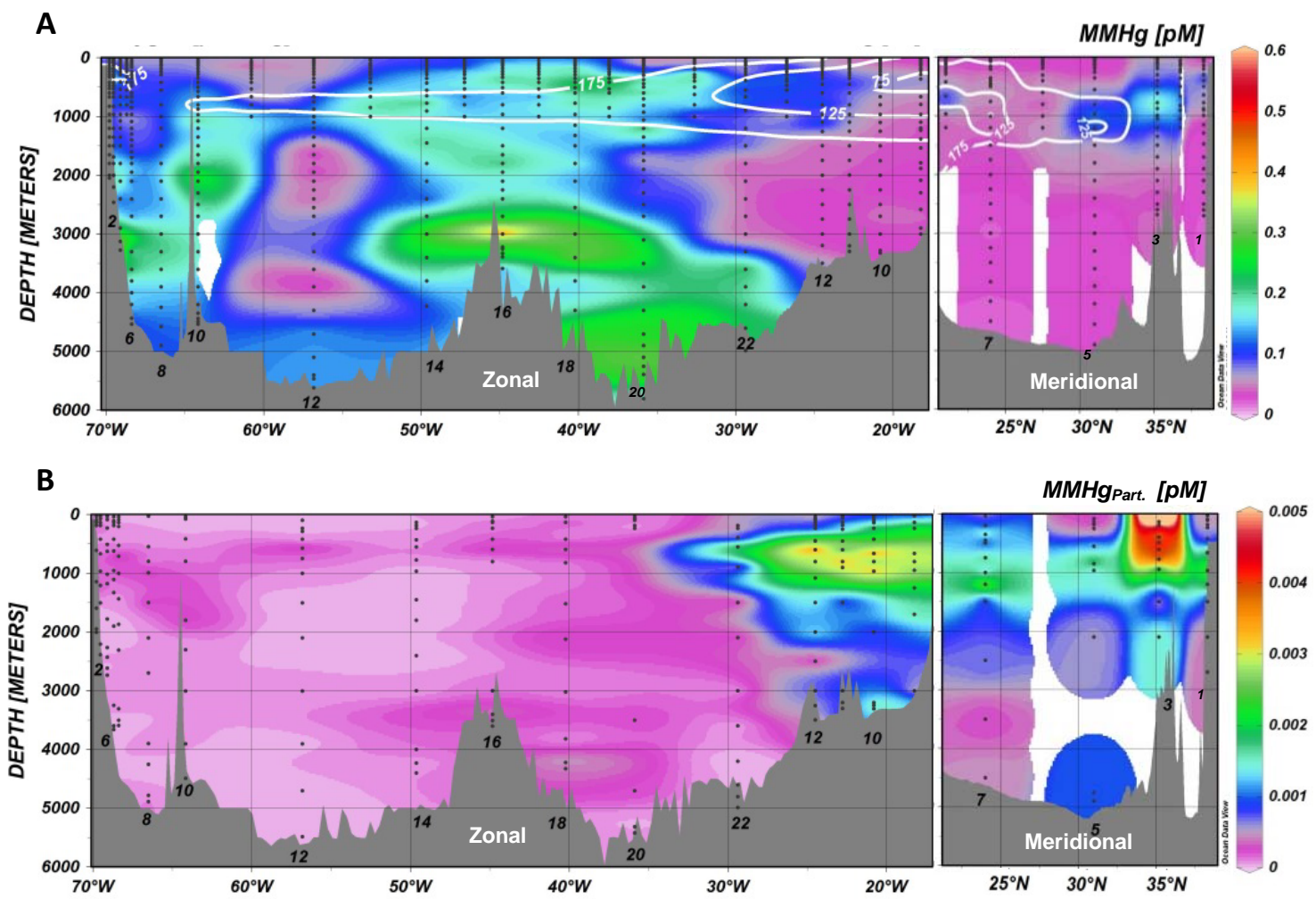
Figure 7

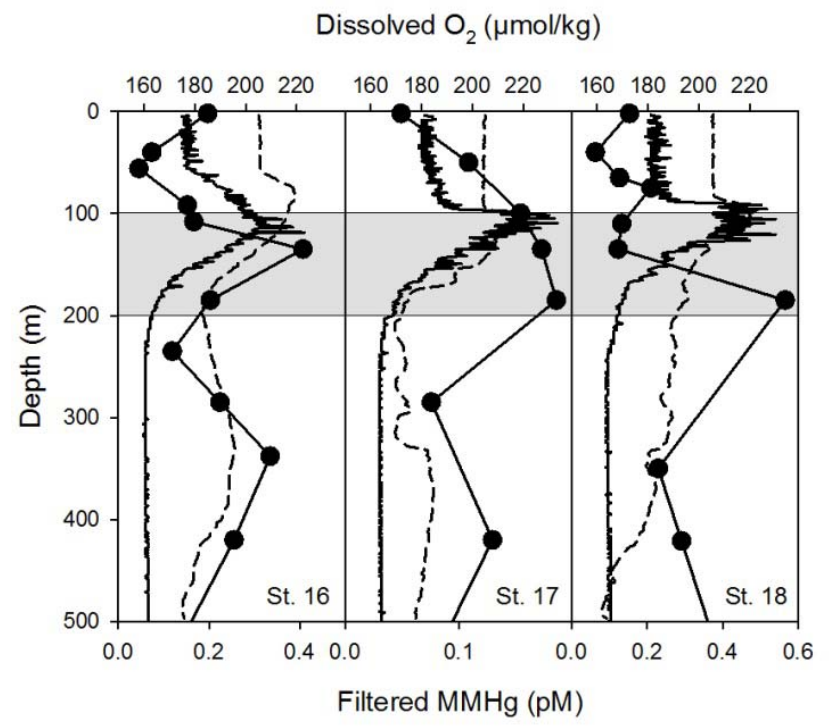


Figure 8

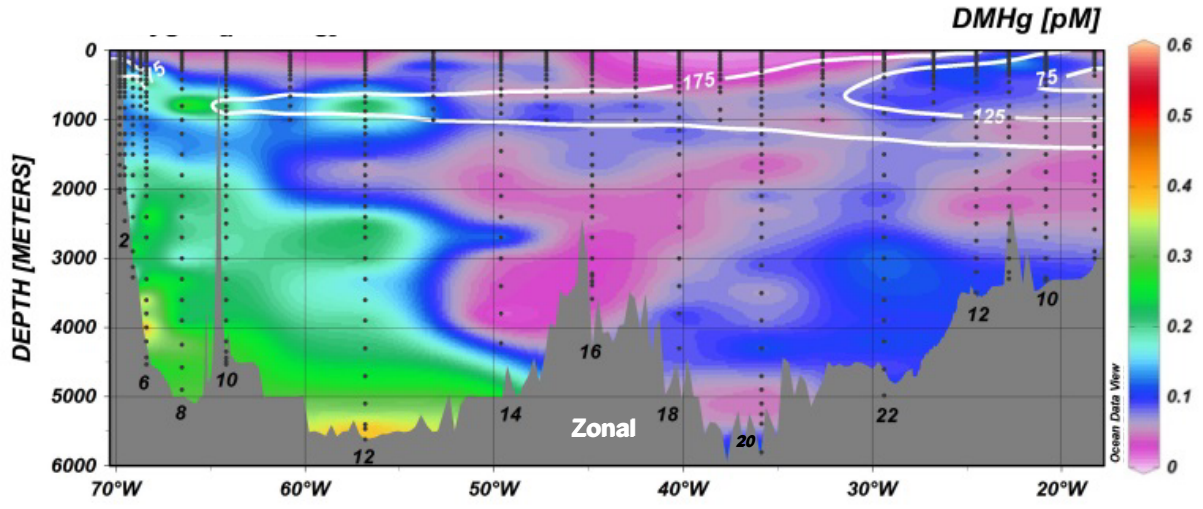


Figure 9

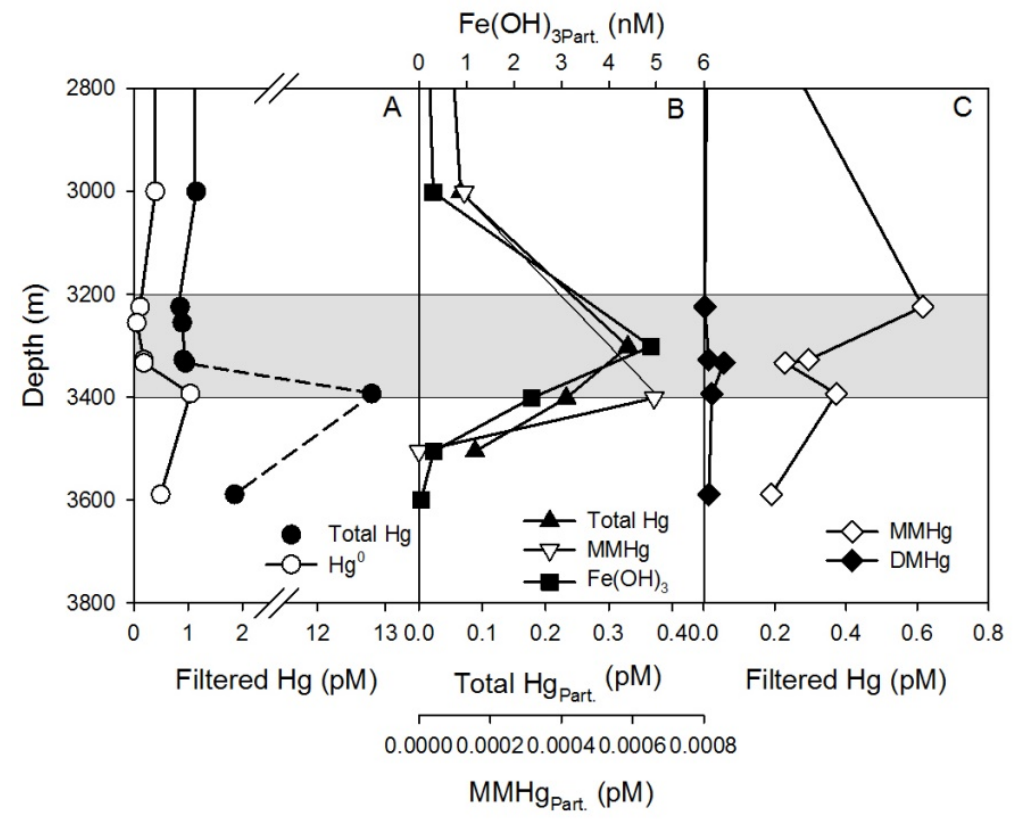

